\title{
Cross metathesis-mediated synthesis of hydroxamic acid derivatives
}

\author{
Shital Kumar Chattopadhyay ", Subhankar Ghosh and Suman Sil
}

\author{
Full Research Paper \\ Address: \\ Department of Chemistry, University of Kalyani, Kalyani -741235 , \\ West Bengal, India, Fax: $+91+33+25828282$ \\ Email: \\ Shital Kumar Chattopadhyay* - skchatto@yahoo.com \\ * Corresponding author \\ Keywords: \\ a-amino acid; catalysis; cross metathesis; hydroxamates
}

\author{
Beilstein J. Org. Chem. 2018, 14, 3070-3075. \\ doi:10.3762/bjoc. 14.285 \\ Received: 01 August 2018 \\ Accepted: 29 November 2018 \\ Published: 17 December 2018 \\ This article is part of the thematic issue "Progress in metathesis \\ chemistry III". \\ Guest Editors: K. Grela and A. Kajetanowicz
}

(C) 2018 Chattopadhyay et al.; licensee Beilstein-Institut.

License and terms: see end of document.

\begin{abstract}
An alternative synthesis of $\alpha, \beta$-unsaturated hydroxamates via cross metathesis between a class-I olefin and $N$-benzyloxyacrylamide is reported. The reaction proceeds better in the presence of Grubbs' second generation catalyst within short time and in good yields (57-85\%) with a range of substrates. Subsequent hydrogenation of each of the CM products delivers the title compounds in moderate to very good yield (70-89\%). An important demonstration of the protocol is the preparation of the unusual amino acid component of the bioactive cyclic peptide Chap-31.
\end{abstract}

\section{Introduction}

Cross-metathesis reactions (CM) have rapidly grown [1-3] to be a reliable method for the preparation of functionalized alkenes and derivatives thereof. Intricacies regarding the electronic nature of olefins, their substitution patterns and steric demands are more or less settled through the works of many workers in many reports [4-7]. Yet, a number of new reports describing the CM-mediated synthesis of functionalized alkenes of various kinds continue to appear. For example, cross metathesis with acrylates [8-10], $\alpha, \beta$-unsaturated acid chlorides [11], acrylamides [12-14], vinyl sulfones [15], vinylphosphine oxides [16], vinyl phosphonates [17], enones [18], and nitrile functionalities $[19,20]$ have been shown to yield shorter routes to com- pounds of interest as well as for green chemical applications $[21,22]$.

Hydroxamates belong to a class of valuable biologically relevant compounds of proven record of utility. For example, the hydroxamate SAHA (1, Figure 1) [23] and the didehydrohydroxamate TSA (2) [24], display useful anticancer properties through inhibition of histone deacetylase enzymes (HDAc) and are used as FDA-approved drugs. Similarly, the cyclic peptide Chap-31 (3) [25] with a terminal hydroxamic acid residue has shown promising anticancer activity. Access to such derivatives usually involves the preparation of the corresponding acid 
<smiles>O=C(CCCCCCC(=O)Nc1ccccc1)NO</smiles>

1, SAHA<smiles>CC(/C=C/C(=O)NO)=C\C(C)C(=O)c1ccc(N(C)C)cc1</smiles>

2, TSA<smiles>CCC(C)[C@H]1NC(=O)[C@H](Cc2ccc(OC)cc2)NC(=O)[C@H](CCCCCC(=O)NO)NC(=O)[C@@H]2CCCN2C1=O</smiles>

3, Chap-31

Figure 1: Some bioactive molecules containing hydroxamate functionality.

and subsequent amide bond formation with hydroxylamines. Although this two-step protocol is widely used, a direct access to $\alpha, \beta$-unsaturated and saturated hydroxamates from cross metathesis of alkenes may prove to be of advantage. In continuation of our earlier studies $[26,27]$ on HDAC inhibitors, we herein report a direct access to $\alpha, \beta$-unsaturated hydroxamates through cross-metathesis reaction.

\section{Results and Discussion}

It is known that a CM reaction between a class-I olefin and a class-II olefin proceeds better in the presence of 2 nd generation catalysts. Accordingly, $\mathrm{CM}$ between 1-decene $\left(4, \mathrm{R}=\mathrm{C}_{7} \mathrm{H}_{15}\right)$ and $N$-benzyloxyacrylamide 5 (Scheme 1 ) was attempted with Grubbs' second generation catalyst [(1,3-bis(2,4,6-trimethylphenyl)-2-imidazolidinylidene)dichloro(phenylmethylene) (tricyclohexylphosphine)ruthenium, G-II]. After some experimentation, it was found that the reaction proceeds quickly in refluxing dichloromethane to provide the CM product 6 $\left(\mathrm{R}=\mathrm{C}_{7} \mathrm{H}_{15}\right)$ in $81 \%$ yield. The yield of 6 was improved to $84 \%$ when Hoveyda-Grubbs 2nd generation catalyst [1,3-bis-(2,4,6trimethylphenyl)-2-imidazolidinylidene]dichloro(o-isopropoxy- phenylmethylene)ruthenium] (HG-II) was used under identical conditions. Hydrogenation of the later in the presence of $\mathrm{Pd}(\mathrm{OH})_{2} / \mathrm{C}$ proceeded uneventfully resulting in the saturation of the double bond as well as concommitant deprotection of the $O$-benzyl group. The one-pot CM-hydrogenation sequence using the same ruthenium catalyst has recently found applications [28-30]. However, similar attempts in our case, i.e., direct conversion of $\mathbf{4}+\mathbf{5} \rightarrow \mathbf{7}$ proved to be problematic and conversion to the desired product was not observed under the attempted conditions. An intractable mixture of compounds was the result.

Having established the conditions for stepwise CM and hydrogenation reactions, we extended the study to other substrates (Table 1). For example, the yields of the two steps for dodecene forming $\mathbf{6 b}$ and $\mathbf{7 b}$ were more or less similar with those for decene when either of the 2nd-generation catalysts was used. However, analogous reaction with bromobutene $4 \mathbf{c}$ as $\mathrm{CM}$ partner proceeded with some compromise in yield with G-II. Moreover, HG-II in this case proved to be less successful. Similarly, the allylbenzene derivatives $\mathbf{4 d} \mathbf{d}-\mathbf{f}$ reacted with more or

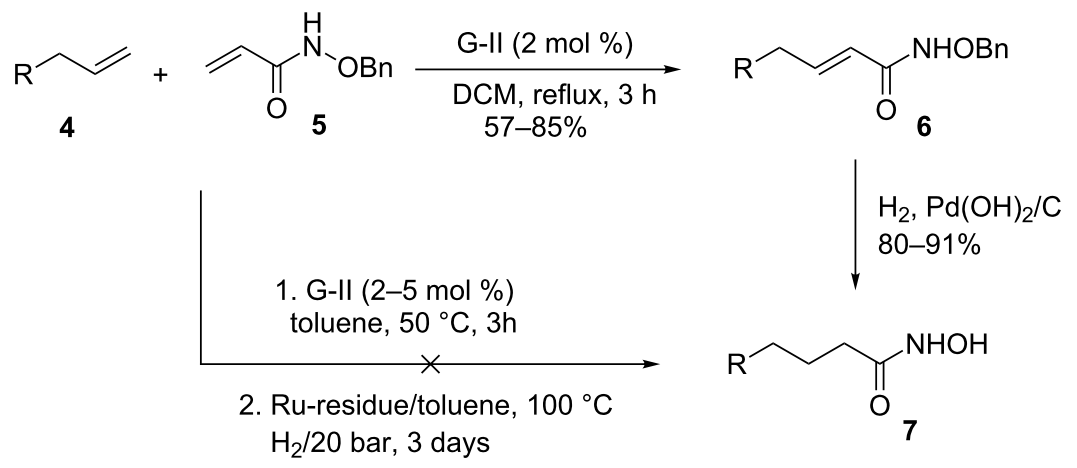

Scheme 1: Cross metathesis between a class-I alkene and $N$-benzyloxyacryl amide. 


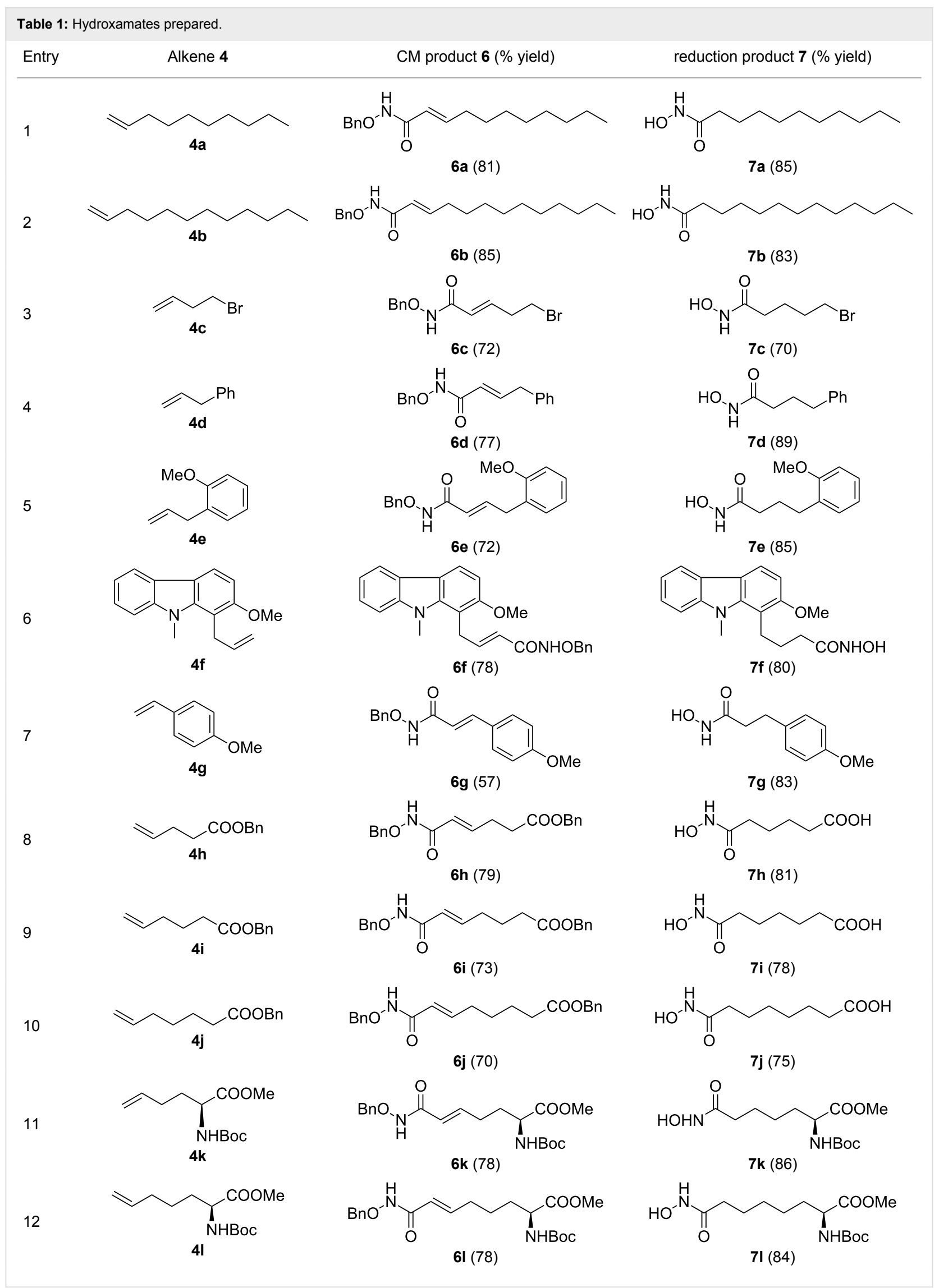


less similar ease with G-II to produce the corresponding CM products $\mathbf{6 d - f}$, respectively. Considerable isomerization (1:1 by ${ }^{1} \mathrm{H}$ NMR) of the CM-product $6 \mathbf{d}$ to the corresponding styrene derivative was noticed when HG-II was used in place of G-II. 6e behaved similarly. Reaction with the styrene derivative $\mathbf{4 g}$ resulted in low conversion to the CM product $6 \mathrm{~g}(57 \%)$. Styrene derivatives, belonging to class-I olefins according to Grubbs' generalizations [31], are indeed known to be a sluggish partner in $\mathrm{CM}$ reactions, with homodimerization to stilbene being a recurring problem.

Alkenes $\mathbf{4 h}-\mathbf{j}$ containing a benzyl ester functionality at two, three and four carbons apart, respectively, participated in the reaction nearly equally well to give the corresponding $\mathrm{CM}$ products $6 \mathbf{h}-\mathbf{j}$. Hydrogenation of each of these compounds separately led to the corresponding saturated hydroxamic acid derivatives $\mathbf{7} \mathbf{h}-\mathbf{j}$ with concommittant cleavage of the terminal benzyl ester functionality. In an extension to the synthesis of the unusual amino acid component of the important anticancer cyclic peptide compound Chap-31, we attempted the cross-metathesis reaction of $\mathrm{N}$-benzyloxyacryl amide $\mathbf{5}$ with the homoallylglycine derivative $4 \mathbf{k}$ (Table 1 , entry 11 ) and the bishomoallyl glycine derivative $4 \mathbf{l}$ (Table 1 , entry 12) [32], separately. Fortunately, both the reactions proceeded well and the desired amino acid derivatives $\mathbf{7 k}$ and $\mathbf{7 1}$ were obtained in good yields after hydrogenation.

\section{Conclusion}

In conclusion, we have developed a direct access to functionalized hydroxamic acid derivatives using a cross-metathesis reaction between $N$-benzyloxyacylamide and a range of terminal alkenes. The products include hydroxamic acid derivatives with a long alkyl chain, aromatic and heteroaromatic cores, halogen residue, carboxylic acid moiety at the terminal relevant position for drug discovery. Moreover, an alternate preparation of the amino acid component of the important cyclic peptide Chap-31 may encourage the preparation of cyclic peptide based HDAC inhibitors. The developed methodology may hence complement the existing literature on the preparation of such class of compounds and may find applications.

\section{Experimental}

\section{General procedure for cross metathesis}<smiles>C=CCCCCCCCC</smiles>

Grubbs' second generation catalyst G-II (10 mg, 2 mol \%), was added to a stirred solution of the olefin 4 a $(158 \mathrm{mg}$, $1.13 \mathrm{mmol})$, and olefin 5 (100 $\mathrm{mg}, 0.56 \mathrm{mmol})$, in anhydrous and degassed $\mathrm{CH}_{2} \mathrm{Cl}_{2}(3 \mathrm{~mL})$ at $\mathrm{rt}$ and the reaction mixture was heated to reflux for $6 \mathrm{~h}$ under argon atmosphere. The reaction mixture was allowed to cool to room temperature and then concentrated in vacuo. The residue was purified by column chromatography on silica gel (hexane/ethyl acetate 60:40) to provide the CM product ( $E$ )- $N$-benzyloxy) undec-2-enamide (6a, $133 \mathrm{mg}, 81 \%$ ) as a colourless viscous liquid.

IR (neat): $3183,3064,2926,2855,1669,1683 \mathrm{~cm}^{-1} ;{ }^{1} \mathrm{H}$ NMR (400 MHz, DMSO-d $)_{6} \delta 11.15$ (s, 1H, NH,), 7.38-7.29 (m, 5H, $\mathrm{ArH}), 6.74-6.67(\mathrm{~m}, 1 \mathrm{H}, \mathrm{C} 3-\mathrm{H}), 5.72(\mathrm{~d}, J=15.2 \mathrm{~Hz}, 1 \mathrm{H}$, C2-H), 4.80 (s, 2H, OCH2-), 2.08 (q, $J=6.8 \mathrm{~Hz}, 2 \mathrm{H}, \mathrm{C} 4-\mathrm{H})$, 1.33 (brs, $\left.3 \mathrm{H}, \mathrm{CH}_{2}\right), 1.12$ (s, $\left.12 \mathrm{H}, \mathrm{CH}_{2}\right), 0.81$ (t, $J=6.8 \mathrm{~Hz}, 3 \mathrm{H}$, C11-H3); ${ }^{13} \mathrm{C}$ NMR (100 MHz, DMSO-d $d_{6} \delta 163.4$ (CO), 144.3 (C3), 136.4 (ArC), $129.2(\mathrm{ArCH}), 128.7(\mathrm{ArCH}), 121.1(\mathrm{C} 2)$, $77.4\left(\mathrm{OCH}_{2}\right), 31.8(\mathrm{C} 4), 31.7(\mathrm{C} 5), 29.3\left(\mathrm{CH}_{2}\right), 29.1\left(\mathrm{CH}_{2}\right)$, $29.0\left(\mathrm{CH}_{2}\right), 28.2\left(\mathrm{CH}_{2}\right), 22.6\left(\mathrm{CH}_{2}\right), 14.3(\mathrm{C} 11)$; HRMS (TOF MS ES $\left.{ }^{+}\right) m / z:[\mathrm{M}+\mathrm{Na}]^{+}$calcd for $\mathrm{C}_{18} \mathrm{H}_{27} \mathrm{NNaO}_{2}, 312.1939$; found, 312.1956 .

\section{General procedure for hydrogenation}

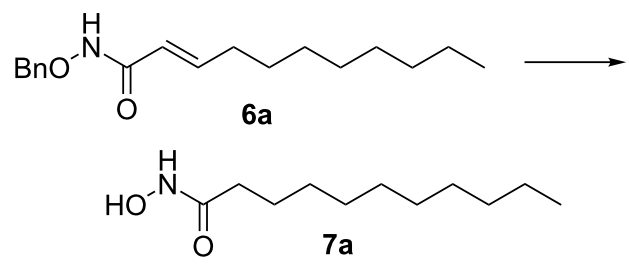

CM product 6a $(50 \mathrm{mg}, 0.17 \mathrm{mmol})$ was taken in a $\mathrm{MeOH}$ $(3 \mathrm{~mL})$ containing 1 drop of TFA [33]. Then $\mathrm{Pd}(\mathrm{OH})_{2}(10 \mathrm{mg})$ was added and the solution was degassed several times. Hydrogen gas was let in and the resulting heterogeneous mixture was vigorously stirred at atmospheric pressure for $2 \mathrm{~h}$. It was filtered through Celite, the filter cake was washed with methanol $(5 \mathrm{~mL})$ and the combined filtrate was concentrated in vacuo. The residue was purified by column chromatography on silica gel $\left(\mathrm{CHCl}_{3} / \mathrm{MeOH} 97: 3\right)$ to provide the product $N$-hydroxyundecanamide $7 \mathbf{a}(85 \%)$ as a colorless solid.

Mp $85{ }^{\circ} \mathrm{C}$; IR (neat): 3259, 3058, 2956, 1663, $1624 \mathrm{~cm}^{-1}$; ${ }^{1} \mathrm{H}$ NMR (400 MHz, DMSO- $\left.d_{6}\right) \delta 10.52$ (s, 1H, NH), 8.93 (brs, 1H, OH), 1.92 (t, $J=7.2 \mathrm{~Hz}, 2 \mathrm{H}, \mathrm{C} 2-\mathrm{H}), 1.44$ (m, 2H, C3-H), $1.19\left(\mathrm{~s}, 14 \mathrm{H}, 7 \times \mathrm{CH}_{2}\right), 0.81(\mathrm{t}, J=6.8 \mathrm{~Hz}, 3 \mathrm{H}, \mathrm{C} 11-\mathrm{H})$; ${ }^{13} \mathrm{C}$ NMR (100 MHz, DMSO- $\left.d_{6}\right) \delta 170.4(\mathrm{CO}), 32.6(\mathrm{C} 2), 31.6$ (C3), $29.3\left(\mathrm{CH}_{2}\right), 29.3\left(\mathrm{CH}_{2}\right), 29.1\left(\mathrm{CH}_{2}\right), 28.9\left(\mathrm{CH}_{2}\right), 25.5$ $\left(\mathrm{CH}_{2}\right), 22.5\left(\mathrm{CH}_{2}\right), 14.3$ (C11); HRMS (TOF MS ES $\left.{ }^{+}\right) \mathrm{m} / \mathrm{z}$ : $[\mathrm{M}+\mathrm{Na}]^{+}$calcd for $\mathrm{C}_{11} \mathrm{H}_{23} \mathrm{NNaO}_{2}, 224.1626$; found, 224.1638 . 


\section{Supporting Information}

\section{Supporting Information File 1}

Analytical data of all new compounds as well as copies of their ${ }^{1} \mathrm{H}$ and ${ }^{13} \mathrm{C}$ NMR spectra.

[https://www.beilstein-journals.org/bjoc/content/ supplementary/1860-5397-14-285-S1.pdf]

\section{Acknowledgements}

We are thankful to DST New Delhi, for funds (EMR/2017/ 001336), and University of Kalyani for assistance.

\section{References}

1. O'Leary, D. J.; O'Neil, G. W. Cross-Metathesis. In Handbook of Metathesis; Grubbs, R. H.; Wenzel, A. G.; O'Leary, D. J.; Khosravi, E., Eds.; Wiley-VCH Verlag GmbH \& Co. KGaA: Weinheim, Germany, 2015; Vol. 2, pp 171-294. doi:10.1002/9783527674107.ch16

2. Zukowska, K.; Grela, K. In Comprehensive Organic Synthesis, 2nd ed.; Knochel, P.; Molander, G. A., Eds.; Elsevier: Amsterdam, Netherlands, 2014; Vol. 5, pp 1257-1301. doi:10.1016/b978-0-08-097742-3.00527-9

3. Connon, S. J.; Blechert, S. Angew. Chem., Int. Ed. 2003, 42, 1900-1923. doi:10.1002/anie.200200556

4. Zukowska, K.; Grela, K. Cross Metathesis. In Olefin Metathesis-Theory and Practice; Grela, K., Ed.; John Wiley and Sons: Hoboken, NJ, USA, 2014; pp 37-83. doi:10.1002/9781118711613.ch2

5. Chatterjee, A. K. Olefin Cross-Metathesis. In Handbook of Metathesis: Catalyst Development, 1st ed.; Grubbs, R. H., Ed.; Wiley-VCH Verlag GmbH: Weinheim, Germany, 2003; Vol. 10, pp 246-295. doi:10.1002/9783527619481.ch20

6. Montgomery, T. P.; Johns, A. M.; Grubbs, R. H. Catalysts 2017, 7, 87. doi:10.3390/catal7030087

7. Ogba, O. M.; Warner, N. C.; O' Leary, D. J.; Grubbs, R. H. Chem. Soc. Rev. 2018, 47, 4510-4544. doi:10.1039/c8cs00027a

8. Yu, E. C.; Johnson, B. M.; Townsend, E. M.; Schrock, R. R.; Hoveyda, A. H. Angew. Chem., Int. Ed. 2016, 55, 13210-13214. doi:10.1002/anie.201608087

See for a recent reference.

9. Biermann, U.; Meier, M. A. R.; Butte, W.; Metzger, J. O. Eur. J. Lipid Sci. Technol. 2011, 113, 39-45. doi:10.1002/ejlt.201000109

10. Bailey, G. A.; Fogg, D. E. J. Am. Chem. Soc. 2015, 137, 7318-7321. doi:10.1021/jacs.5b04524

11. Ferrié, L.; Bouzbouz, S.; Cossy, J. Org. Lett. 2009, 11, 5446-5448. doi:10.1021/ol9021386

12. Choi, T.-L.; Chatterjee, A. K.; Grubbs, R. H. Angew. Chem., Int. Ed. 2001, 40, 1277-1279. doi:10.1002/1521-3773(20010401)40:7<1277::aid-anie1277>3.0.co;2-e

13. Guan, J.; Hachey, M.; Puri, L.; Howieson, V.; Saliba, K. J.; Auclair, K. Beilstein J. Org. Chem. 2016, 12, 963-968. doi:10.3762/bjoc.12.95 See for a recent report of $\mathrm{CM}$ with $\mathrm{N}$-alkylated acrylamides.

14. Boufroura, H.; Mauduit, M.; Drège, E.; Joseph, D. J. Org. Chem. 2013, 78, 2346-2354. doi:10.1021/jo302435a See for CM with Weinreb's amide.

15. Michrowska, A.; Bieniek, M.; Kim, M.; Klajn, R.; Grela, K. Tetrahedron 2003, 59, 4525-4531. doi:10.1016/s0040-4020(03)00682-3
16. Demchuk, O. M.; Pietrusiewicz, K. M.; Michrowska, A.; Grela, K. Org. Lett. 2003, 5, 3217-3220. doi:10.1021/ol035011m

17. Malla, R. K.; Ridenour, J. N.; Spilling, C. D. Beilstein J. Org. Chem. 2014, 10, 1933-1941. doi:10.3762/bjoc.10.201

18. Abbas, M.; Leitgeb, A.; Slugovc, C. Synlett 2013, 24, 1193-1196. doi:10.1055/s-0033-1338425

19. Bidange, J.; Fischmeister, C.; Bruneau, C.; Dubois, J.-L.; Couturier, J.-L. Monatsh. Chem. 2015, 146, 1107-1113. doi:10.1007/s00706-015-1480-1 See for a detailed study of $\mathrm{CM}$ with acrylonitrile.

20. Bruneau, C.; Fischmeister, C.; Miao, X.; Malacea, R.; Dixneuf, P. H. Eur. J. Lipid Sci. Technol. 2010, 112, 3-9. doi:10.1002/ejlt.200900105

21. Bilel, H.; Hamdi, N.; Zagrouba, F.; Fischmeister, C.; Bruneau, C. RSC Adv. 2012, 2, 9584. doi:10.1039/c2ra21638h

22. Miao, X.; Malacea, R.; Fischmeister, C.; Bruneau, C.; Dixneuf, P. H. Green Chem. 2011, 13, 2911. doi:10.1039/c1gc15569e

23. Mann, B. S.; Johnson, J. R.; Cohen, M. H.; Justice, R.; Pazdur, R. Oncologist 2007, 12, 1247-1252. doi:10.1634/theoncologist.12-10-1247

24. Yoshida, M.; Kijima, M.; Akita, M.; Beppu, T. J. Biol. Chem. 1990, 265, 17174.

25. Komatsu, Y.; Tomizaki, K.-Y.; Tsukamoto, M.; Kato, T.; Nishino, N.; Sato, S.; Yamori, T.; Tsuruo, T.; Furumai, R.; Yoshida, M.; Horinouchi, S.; Hayashi, H. Cancer Res. 2001, 61, 4459.

26. Mukherjee, J.; Sil, S.; Chattopadhyay, S. K. Beilstein J. Org. Chem. 2015, 11, 2487-2492. doi:10.3762/bjoc. 11.270

27. Mukherjee, J. P.; Sil, S.; Chattopadhyay, S. K. Tetrahedron Lett. 2016, 57, 739-742. doi:10.1016/j.tetlet.2016.01.005

28. Schmidt, B.; Pohler, M. Org. Biomol. Chem. 2003, 1, 2512. doi:10.1039/b303441k

29. Miao, X.; Fischmeister, C.; Bruneau, C.; Dixneuf, P. H.; Dubois, J.-L.; Couturier, J.-L. ChemSusChem 2012, 5, 1410-1414. doi:10.1002/cssc.201200086

30. Skowerski, K.; Białecki, J.; Czarnocki, S. J.; Żukowska, K.; Grela, K. Beilstein J. Org. Chem. 2016, 12, 5-15. doi:10.3762/bjoc.12.2

31. Chatterjee, A. K.; Choi, T.-L.; Sanders, D. P.; Grubbs, R. H. J. Am. Chem. Soc. 2003, 125, 11360-11370. doi:10.1021/ja0214882

32. Chattopadhyay, S. K.; Sil, S.; Mukherjee, J. P. Beilstein J. Org. Chem. 2017, 13, 2153-2156. doi:10.3762/bjoc.13.214

33. Pahari, A. K.; Mukherjee, J. P.; Chattopadhyay, S. K. Tetrahedron 2014, 70, 7185-7191. doi:10.1016/j.tet.2014.07.045 


\section{License and Terms}

This is an Open Access article under the terms of the Creative Commons Attribution License

(http://creativecommons.org/licenses/by/4.0). Please note that the reuse, redistribution and reproduction in particular requires that the authors and source are credited.

The license is subject to the Beilstein Journal of Organic Chemistry terms and conditions:

(https://www.beilstein-journals.org/bjoc)

The definitive version of this article is the electronic one which can be found at:

doi:10.3762/bjoc. 14.285 